\title{
Calixarenes, chemical chameleons
}

\author{
Erik van Dienst, Wouter I. Iwema Bakker, Johan F. J. Engbersen, Willem Verboom, \\ and David N. Reinhoudt"
}

Laboratory of Organic Chemistry, University of Twente, P.O. Box 217, 7500 AE Enschede, The Netherlands.

\begin{abstract}
Methods for the synthesis of selectively functionalized calix[4]arenes have been developed. These functionalized calix[4]arenes have been coupled to cavitands and cyclodextrins. A number of practical applications of calix[4]arenes are described.
\end{abstract}

\section{INTRODUCTION}

In supramolecular or 'host-guest' chemistry the attention is focussed on the mimicry of natural molecular recognition processes in which weak, non-covalent interactions between molecules play an important role. Three-dimensional structures, that already have a molecular cavity, are attractive building blocks. Therefore, our efforts concentrate on the selective introduction of functional groups in calix[4]arenes [1,2], in resorcinol-based octols [2] and in cyclodextrins [3]. Secondly we use these compounds as enzyme mimics, in facilitated (membrane) transport, and in ion-selective sensors.

\section{SELECTIVE FUNCTIONALIZATION OF CALIX[4]ARENES}

The cyclic tetramer of the base-catalyzed condensation of $p$-tert-butylphenol with formaldehyde, p-tert-butylcalix[4]arene 1, exists in the cone conformation because of the hydrogen bonds that are present between the four hydroxyl groups at the so-called lower rim. The para positions of the phenol rings form the upper rim.

We have succeeded in the selective functionalization of both the upper and the lower rim of calix[4]arenes.

\section{Selective functionalization of the lower rim}

Partial alkylation of the lower rim. We found that monoalkylation of calix[4]arenes to the corresponding monoalkyl ethers 2 can be performed directly by reaction with an excess of alkylating agent in the presence of 1.2 equivalents of a weak base (CsF) in $N, N$-dimethylformamide (DMF) [4], as an alternative for the selective dealkylation of di- or tetraalkylated calix[4]arenes with $\mathrm{Me}_{3} \mathrm{SiI}$ [5]. A stronger base like $\mathrm{K}_{2} \mathrm{CO}_{3}$ in acetonitrile gave not only the monoalkyl ethers (2) but also the 1,3-dialkyl ethers (3).

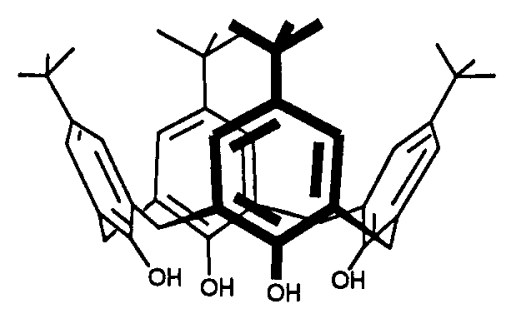

1

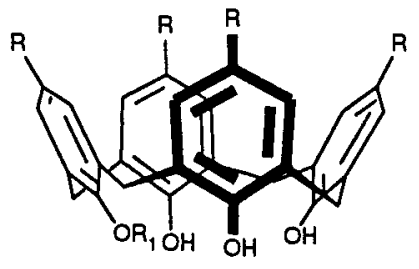

$$
\begin{aligned}
2 R= & H_{1} \underline{t}-\mathrm{Bu} \\
R_{1}= & M e, E t, \text { Allyl, } \\
& \mathrm{CH}_{2} \mathrm{C}(\mathrm{O}) \mathrm{R}
\end{aligned}
$$

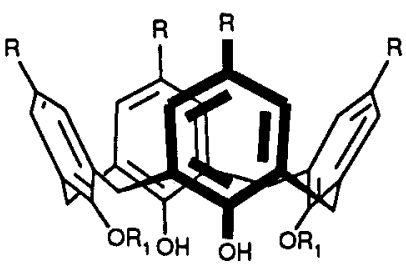

3. $R=H_{1},-B u$

$R_{1}=M e, E t$, Allyl,

$\mathrm{CH}_{2} \mathrm{C}(\mathrm{O}) \mathrm{R}$

Selective alkylation of two diametrically located phenol rings is possible in good yields by reacting calix[4]arenes with 2 equivalents of alkylating agent in acetonitrile, in the presence of 1 equivalent of 
$\mathrm{K}_{2} \mathrm{CO}_{3}[6,7]$. All the products (3) are obtained in the cone conformation and further alkylation does not take place. Alkylation of calix[4]arenes with an excess of $\mathrm{NaH}$ in DMF and 2.2 equivalents of alkylating agent leads to the 1,2-dialkoxycalix[4]arenes 4 (in the cone conformation) in acceptable yields, besides tetrasubstituted calix[4]arenes and starting material [8].

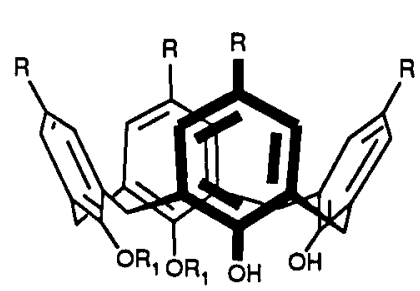

$4 \mathrm{R}_{1}=\mathrm{Me}, \mathrm{Et}$, Allyl,

$\mathrm{CH}_{2} \mathrm{C}(\mathrm{O}) \mathrm{R}$

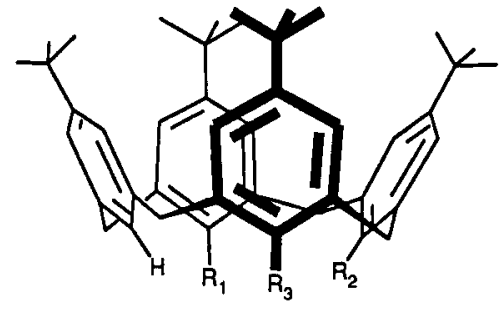

5a $R_{1}=R_{2}=R_{3}=O H$

5b $R_{1}=R_{3}=O H, R_{2}=H$

5c $R_{1}=O H, R_{2}=R_{3}=H$

5d $R_{1}=R_{2}=R_{3}=H$

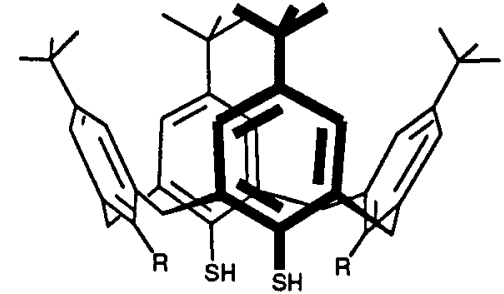

6a $\mathrm{R}=\mathrm{OMe}$

6b $R=H$

Replacement of hydroxyl groups. Besides selective functionalization of the lower rim by alkylation, we also succeeded in the synthesis of partially and fully dehydroxylated calix[4]arenes 5 via the reductive cleavage (K/liq. $\mathrm{NH}_{3}$ ) of the 1,3-bis- and tetrakis(diethyl phosphate) esters of $p$-tert-butylcalix[4]arene [9].

The selective replacement of hydroxyl groups by thiol groups was carried out by modification of the two remaining hydroxyl groups of 1,3-dimethoxycalix[4]arene $\left(2, \mathrm{R}=t-\mathrm{Bu}, \mathrm{R}_{1}=\mathrm{Me}\right)$ and 1,3-di-dehydroxylated calix $[4]$ arene $5 \mathrm{~b}$ to the corresponding $O$-dimethylthiocarbamates. After Newman-Kwart rearrangement to the $S$-dimethylthiocarbamates these compounds were reduced with $\mathrm{LiAlH}_{4}$ to the dithiols 6 [9].

\section{Controlling the conformation of tetrasubstituted calix[4]arenes}

So far, all the functionalized calix[4]arenes discussed are in the cone conformation, due to the presence of hydrogen bonds between hydroxyl groups, or between phenolic hydroxyl groups and the ether oxygens. Calix[4]arenes can adopt three other conformations viz. the partial cone, the 1,2-alternate and the 1,3-alternate [10]. In tetrasubstituted calix[4]arenes with large substituents all these conformers can be formed.

We have found experimental procedures that give tetrasubstituted calix[4]arenes of which the conformation can be predicted by the use of different base and solvent combinations. When the phenolic hydroxyl groups are functionalized with substituents larger then ethyl groups, interconversion between the different conformations is no longer possible [11], and the conformation of the tetrasubstituted calix [4]arene is determined during the alkylation process.

Alkylation of calix[4]arenes with various electrophiles in DMF or acetonitrile at room temperature with $\mathrm{NaH}$ as base leads predominantly to tetrasubstituted calix [4]arenes in the cone conformation, whereas the use of strong potassium bases leads to mixtures of conformers [8].

We found that further alkylation of 1,3-dialkoxycalix[4]arenes 7 , having different substituents $(t-\mathrm{Bu}$, $\mathrm{CHO}, \mathrm{NO}_{2}, \mathrm{Br}$ ) at the para positions of the phenolic rings, with $\mathrm{Cs}_{2} \mathrm{CO}_{3}$ in DMF yielded the tetraalkylated calix[4]arenes 8 in the 1,3-alternate conformation (see scheme 1) [12].

\section{Scheme 1}

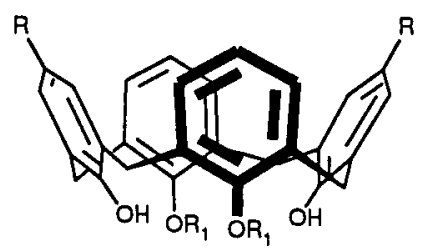

$$
\begin{aligned}
7 \mathrm{R} & =\mathrm{t}-\mathrm{Bu}, \mathrm{CHO}, \mathrm{NO}_{2}, \mathrm{Br} \\
\mathrm{R}_{1} & =\mathrm{CH}_{3} \mathrm{OCH}_{2} \mathrm{CH}_{2}, \underline{\mathrm{n}}-\mathrm{Pr}
\end{aligned}
$$

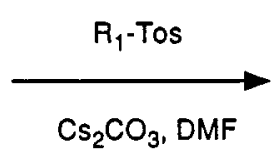

Finally, we have synthesized the 1,2-alternate conformer of tetraethoxy-p-tert-butylcalix[4]arene in acceptable yield by ethylation of anti-1,3-diethoxy-p-tert-butylcalix [4] arene with $\mathrm{KO} t \mathrm{Bu}$ in THF [13]. 


\section{Selective functionalization of the upper rim}

In addition to the selective functionalization of the lower rim of calix[4]arenes our attention also focussed on the selective functionalization of the upper rim. Except for mono-p-allylcalix[4]arene [14] functionalization of the upper rim has always been performed at all the para positions simultaneously. Generally the $p$-tert-butyl groups of $p$-tert-butylcalix[4]arene have to be removed to render the para positions accessible to substitution. Besides fourfold de-tert-butylation [15], we were able to remove selectively two tert-butyl groups from dialkoxy-p-tert-butylcalix[4]arene by making use of the difference in reactivity between phenols and alkylated phenols [6]. This method leads to calix [4]arenes $\mathbf{9}$ in which the two alkylated phenols remain protected at the para position by tert-butyl groups. The difference in reactivity between phenols and alkylated phenols can also be used in the selective functionalization of de-tert-butylated dialkoxycalix[4]arenes. The para positions of the phenols are more reactive towards electrophilic aromatic substitution then those of the alkylated phenol moieties. In this way different electrophiles (e.g. $\mathrm{Br}, \mathrm{NO}_{2}, \mathrm{CHO}$ ) can be introduced at the upper rim in high yields (compounds 10) [6].

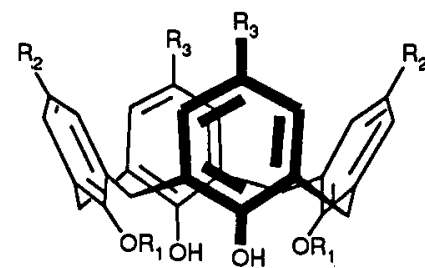

$9 \quad R_{1}=$ alkyl, $R_{2}=\underline{t}-B u, R_{3}=H$

$10 R_{1}=$ alkyl, $R_{2}=H, R_{3}=E$

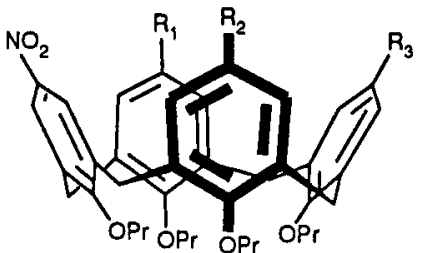

11a $R_{1}=R_{2}=R_{3}=H$

11b $R_{1}=N O_{2}, R_{2}=R_{3}=H$

11c $R_{1}=R_{2}=H, R_{3}=N O_{2}$

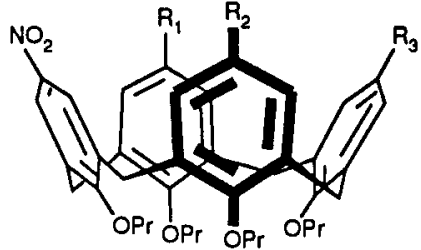

12a $R_{1}=R_{2}=R_{3}=t-B u$

12b $R_{1}=R_{2}=R_{3}=N O_{2}$

12c $R_{1}=R_{2}=t-B u, R_{3}=N O_{2}$

12d $R_{1}=R_{3}=\underline{t}-B u, R_{2}=N O_{2}$

12e $R_{1}=R_{2}=N O_{2}, R_{3}=t-B u$

Selective functionalization of the upper rim can also be performed with calix[4]arenes that are not selectively functionalized at the lower rim. Pochini and co-workers reported the partial introduction of formyl groups at the upper rim of the de-tert-butylated tetrakis(ethoxyethyl) ether of calix[4]arene in the cone conformation, via the Gross formylation [16]. We found that the tetra- $n$-propyl ether of de-tert-butylated calix [4]arene in the cone conformation can be mononitrated in $55 \%$ yield (11a) by the reaction with 15 equivalents of $65 \% \mathrm{HNO}_{3}$ in $\mathrm{CH}_{2} \mathrm{Cl}_{2}$ for 30 minutes [17]. After a prolonged reaction time and the addition of a trace of acetic acid, a mixture of nitrated products is formed from which the 1,2- and the 1,3-dinitrated compounds $11 \mathrm{~b}$ and 11c can be isolated in 10 and $30 \%$ yield, respectively. After nitration of the de-tert-butylated tetrakis(ethoxyethyl) ether of calix[4]arene with acetyl nitrate in $\mathrm{CH}_{2} \mathrm{Cl}_{2}$ (room temperature), only the mononitro (20\%) and the 1,3-dinitro (30-40\%) derivatives could be obtained [18]. Recently, we have found that nitration of tetrasubstituted $p$-tert-butylcalix [4]arenes takes place by direct replacement of the tert-butyl groups by nitro groups (ipso nitration) [19]. When the reaction is carried out with $100 \% \mathrm{HNO}_{3}$ in $\mathrm{CH}_{2} \mathrm{Cl}_{2} / \mathrm{AcOH}$ all the tert-butyl groups are substituted, but under milder conditions $\left(65 \% \mathrm{HNO}_{3}\right)$ the partially nitrated calix[4]arenes 12 are obtained. Also the partial cone and the 1,3-alternate conformers of tetrasubstituted $p$-tert-butylcalix[4]arenes can be nitrated in this way [17].

\section{SELECTIVE FUNCTIONALIZATION OF RESORCINOL-BASED CALIX[4]ARENES}

The acid-catalyzed condensation of resorcinol with various aliphatic and aromatic aldehydes can be directed to give the cyclic tetramer in a conformation (all-cis or cone) in which all the aromatic hydroxyl groups are at one face of the molecule.

The triply bridged, tetrabromo octol 13 [20], in the all-cis conformation, is a key intermediate in our efforts to arrive at selectively functionalized resorcinol-based octols.

Previously, we have reported that two of the four bromo atoms of the triply bridged octol 13 can be removed selectively in $76 \%$ yield [21] by treatment with 5 equivalents of $n$-BuLi and quenching with acid after 15 seconds. After incorporation of the fourth bridge, the two remaining bromo atoms can be replaced by electrophiles $(\mathrm{C}(\mathrm{O}) \mathrm{OMe}, \mathrm{OH})$ via the dilithio compound or by a cyano group via a Rosenmund-von Braun reaction to give cavitands 14. ${ }^{1} \mathrm{H}$ NMR spectroscopy of the carcerand obtained after the reaction of the selectively functionalized cavitand $14(\mathrm{E}=\mathrm{OH})$ with $\mathrm{CH}_{2} \mathrm{BrCl}$ strongly suggests that only one isomer (the $\mathrm{C}$-isomer, in which the molecular cavities of the two cavitand moieties are above each other) is formed. 


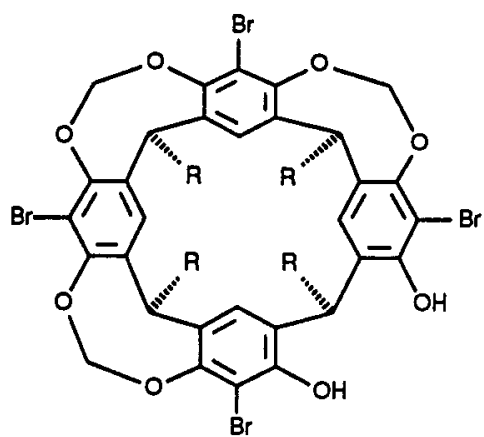

13

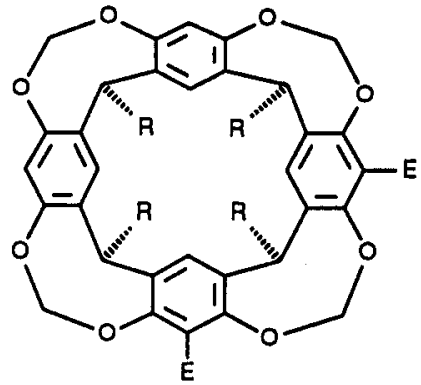

$14 E=C N, C(O) O M e, O H$

Recently, we managed to couple the triply bridged octol 13 to an upper rim-1,3-difunctionalized calix [4] arene via two amide or ester linkers (compound 15) [22].

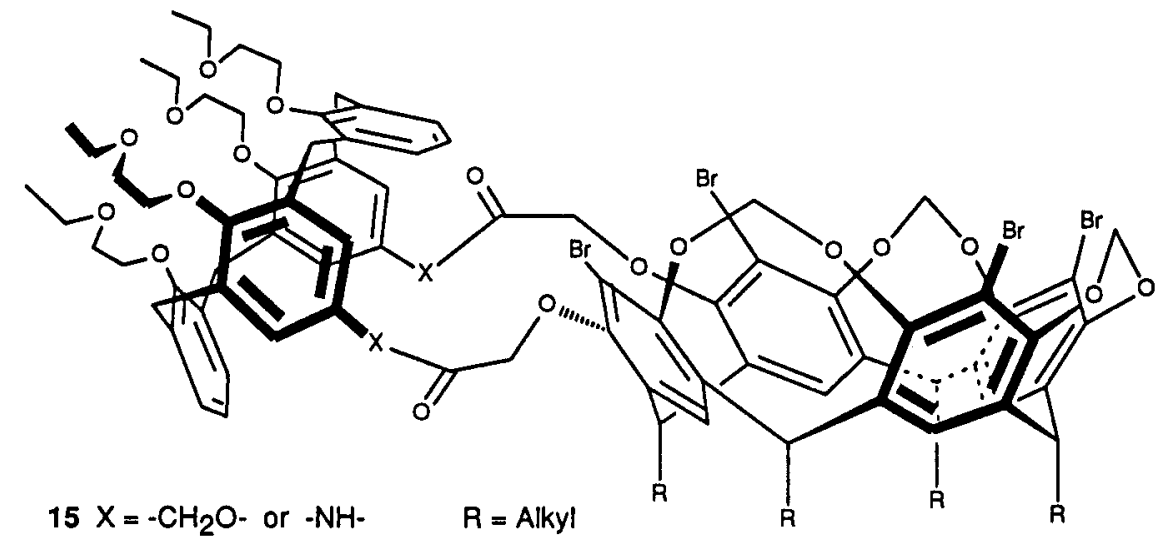

\section{SELECTIVE FUNCTIONALIZATION OF CYCLODEXTRINS}

Cyclodextrins are a group of cyclic D-glucose oligomers (e.g. $\beta$-cyclodextrin contains 7 glucose units) which are soluble in water and have a hydrophobic molecular cavity. We are using cyclodextrins to synthesize new water soluble host compounds by coupling to other building blocks like calix [4]arenes. In this way we hope to arrive at more defined molecular cavities for neutral guests which can be used in molecular transport and catalysis.

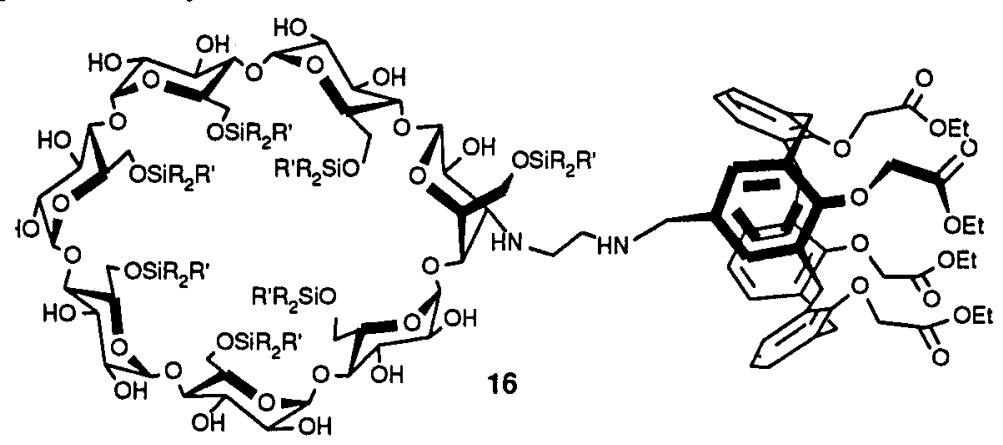

Different methods for monofunctionalization of the secondary hydroxylic side of $\beta$-cyclodextrin have been investigated. The monofunctionalization of the lipophilic heptakis(6-O-tert-butyldimethylsilyl)$\beta$-cyclodextrin by means of converting the two secondary hydroxyl groups from the same glucose unit to a manno-epoxide was reported by Pregel and Buncel [23]. We have exploited this method for the introduction of amino nucleophiles (like ethylenediamine and lithium azide) to the secondary hydroxylic face of the cyclodextrin [24].

The ethylenediamine-substituted silylated $\beta$-cyclodextrin has been coupled to mono- $p$-formyl-calix[4]arene tetraester, leading to compound 16 [24]. 


\section{APPLICATIONS OF CALIX[4]ARENES}

\section{Non linear optics}

The described synthetic methods were used to design and synthesize a number of calix[4]arenes for different applications. First of all the nitrocalixarenes, which have a high dipole moment, appeared to be very promising for second order non linear optics $12 \mathrm{~b}$ [17].

\section{Organ imaging}

Other applications are mainly in the field of cation complexation. This work was started with the development of a kinetically stable rubidium complex for organ imaging [25]. Calixspherand 17 was synthesized and shown to form kinetically stable complexes with $\mathrm{Na}^{+}, \mathrm{K}^{+}$, and $\mathrm{Rb}^{+}$. For medical application, however, it was necessary to increase the stability of the rubidium complex, therefore a number of new calixspherands were synthesized of which 18 shows a strongly increased kinetic stability of the $\mathrm{Rb}^{+}$complex [26].

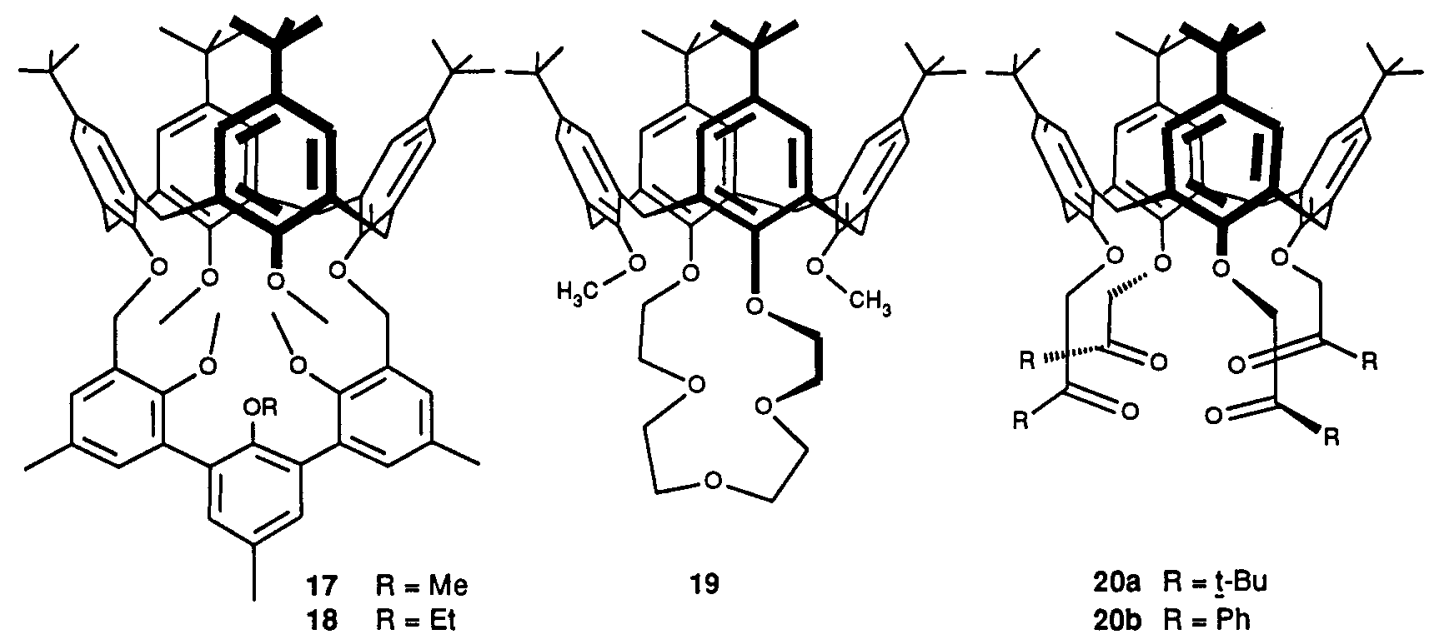

\section{Ion sensitive field effect transistors}

The coupling of $p$-tert-butylcalix[4]arene with a polyethylene glycol chain afforded the calixcrown 19 $[25,27]$, which is a highly selective ionophore for $\mathrm{K}^{+}$, as was shown by the two-phase picrate extraction method [27]. With calixcrown 19 a $\mathrm{K}^{+}$-sensor based on ISFET-technology was developed with a potentiometric selectivity coefficient $\left(\log \mathrm{k}_{\mathrm{K} / \mathrm{Na}}\right.$ ) of -2.2 [28]. A sodium selective ISFET was obtained with the calix[4]arene tetraketones 20 with $\log \mathrm{k}_{\mathrm{Na} / \mathrm{K}}$ of -1.9 [29].

\section{Transport through supported liquid membranes}

The calixcrown 19 was also used for the selective transport of $\mathrm{K}^{+}$through a supported liquid membrane (SLM). In the presence of a hundred fold excess of sodium the potassium flux is still 2.7 times the sodium flux [30]. Not only cations can be transported through SLM's but also neutral molecules like ureum. For the transport of ureum the best results are obtained with the uranylcalixsalophene 21 [31].

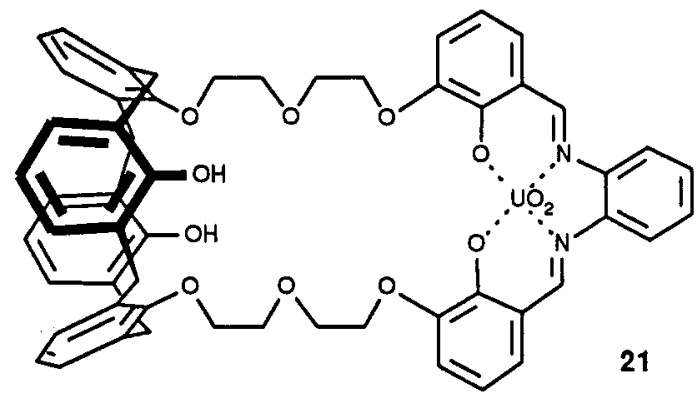




\section{REFERENCES}

1 C.D. Gutsche, Calixarenes, monographs in supramolecular chemistry, J.F. Stoddart (ed.), Royal Society of Chemistry, Cambridge, (1989).

2 J. Vicens and V. Böhmer (eds.), Calixarenes. A Versatile Class of Compounds, Kluwer Academic Publishers, Dordrecht, (1991).

3 R. Breslow, Pure \& Appl. Chem. 62, 1859-1866, (1990).

4 L.C. Groenen, B.H.M. Ruël, A. Casnati, W. Verboom, A. Pochini, R. Ungaro, S. Harkema and D.N. Reinhoudt, Tetrahedron 47, 8379-8384, (1991).

5 A. Casnati, A. Arduini, E. Ghidini, A. Pochini and R. Ungaro, Tetrahedron 47, 2221-2228, (1991).

6 a) J.-D. van Loon, A. Arduini, W. Verboom, R. Ungaro, G.J. van Hummel, S. Harkema and D.N. Reinhoudt, Tetrahedron Lett. 30, 2681-2684, (1989). b) J.-D. van Loon, A. Arduini, L. Coppi, W. Verboom, A. Pochini, R. Ungaro, S. Harkema and D.N. Reinhoudt, J. Org. Chem. 55, 5639-5646, (1990).

7 E.M. Collins, M.A. McKervey and S.J. Harris, J. Chem. Soc., Perkin Trans. $1372-374$, (1989).

8 L.C. Groenen, B.H.M. Ruël, A. Casnati, P. Timmerman, W. Verboom, S. Harkema, A. Pochini, R. Ungaro and D.N. Reinhoudt, Tetrahedron Lett. 32, 2675-2678, (1991).

9 Y. Ting, W. Verboom, L.C. Groenen, J.-D. van Loon and D.N. Reinhoudt, J. Chem. Soc., Chem. Commun. 1432-1433, (1990).

10 C.D. Gutsche, B. Dhawan, J.A. Levine, K.H. No and L.J. Bauer, Tetrahedron 39, 409-426, (1983).

11 a) K. Araki, K. Iwamoto, S. Shinkai and T. Matsuda, Chem. Lett. 1747-1750, (1989). b) K. Iwamoto, K. Araki and S. Shinkai, J. Org. Chem. 56, 4955-4962, (1991).

12 W. Verboom, S. Datta, Z. Asfari, S. Harkema and D.N. Reinhoudt, J. Org. Chem. in press.

13 L.C. Groenen, J.-D. van Loon, W. Verboom, S. Harkema, A. Casnati, R. Ungaro, A. Pochini, F. Ugozzoli and D.N. Reinhoudt, J. Am. Chem. Soc. 113, 2385-2392, (1991).

14 C.D. Gutsche and L.-G. Lin, Tetrahedron 42, 1633-1640, (1986).

15 H. Kämmerer, G. Happel, V. Böhmer and D. Rathay, Monatsh. 109, 767-773, (1978).

16 A. Arduini, G. Manfredi, A. Pochini, A.R. Sicuri and R. Ungaro, J. Chem. Soc., Chem. Commun., 936-937, (1991).

17 E. Kelderman, L. Derhaeg, G. Heesink, W. Verboom, J.F.J. Engbersen, N. van Hulst, A. Persoons and D.N. Reinhoudt, Angew. Chem. in press.

18 J.-D. van Loon, PhD-thesis University of Twente, pp. 107-126, (1992).

19 W. Verboom, A. Durie, R.J.M. Egberink, Z. Asfari and D.N. Reinhoudt, J. Org. Chem. 57, 1313-1316, (1992).

20 D.J. Cram, S. Karbach, H.-E. Kim, C.B. Knobler, E.F. Maverick, J.L. Ericson and R.C. Helgeson, J. Am. Chem. Soc. $110,2229-2237$, (1988).

21 P. Timmerman, M.G.M.A. van Mook, W. Verboom, G.J. van Hummel, S. Harkema and D.N. Reinhoudt, Tetrahedron Lett. 33, 3377-3380, (1992).

22 P. Timmerman, W. Verboom and D.N. Reinhoudt, unpublished results.

23 M.J. Pregel and E. Buncel, Can. J. Chem. 69, 130-137, (1991).

24 E. van Dienst, I.M. Eissink, B.H.M. Ruël, J.F.J. Engbersen and D.N. Reinhoudt, unpublished results.

25 P.J. Dijkstra, J.A.J. Brunink, K.-E. Bugge, D.N. Reinhoudt, S. Harkema, R. Ungaro, F. Ugozzoli and E. Ghidini, J. Am. Chem. Soc. 111, 7567-7575 (1989).

26 W.I. Iwema Bakker, R. Ostaszewski, C. Khoo-Beattie, W. Verboom, S. Harkema and D.N. Reinhoudt, unpublished results.

27 E. Ghidini, F. Ugozzoli, R. Ungaro, S. Harkema, A.A. El-Fadl and D.N. Reinhoudt, J. Am. Chem. Soc. $112,6979-6985(1990)$.

28 E.J.R. Südholter, P.D. van der Wal, M. Skowronska-Ptasinska, A. van den Berg, P. Bergveld and D.N. Reinhoudt, Recl. Trav. Chim. Pays-Bas 109, 222-225 (1990).

29 J.A.J. Brunink, J.R. Haak, J.G. Bomer, D.N. Reinhoudt, M.A. McKervey and S.J. Harris, Anal. Chim. Acta 254, 75-80 (1991).

30 W.F. Nijenhuis, E.G. Buitenhuis, F. de Jong, E.J.R. Südholter and D.N. Reinhoudt, J. Am. Chem. Soc. $113,7963-7968$ (1991).

31 W.F. Nijenhuis, A.R. van Doorn, A.M. Reichwein, F. de Jong and D.N. Reinhoudt, J. Am. Chem. Soc. $113,3607-3608$ (1991). 